\title{
RBGO-2018-0040.R1_Original article
}

\section{Negative correlation between Placental Growth Factor and Endocan-1 in women with preeclampsia}

Correlação negativa entre fator de crescimento placentário e Endocan-1 em mulheres com preeclampsia

\section{Keywords}

Pregnancy-induced hypertension; Preeclampsia; Endothelial function; Biomarkers; Preeclampsia, cytokines

\section{Descritores}

Hipertensão induzida pela gravidez; Pré-eclâmpsia; Função endotelial; Biomarcadores; Pré-eclâmpsia, citocinas

\section{Abstract}

Objective: To analyse Endocan-1, a biomarker of vascular endothelial related pathologies, and Placental growth factor (PIGF), an angiogenic factor and a placental dysfunction marker in patients with pre-eclampsia (PE).

Methods: Case-control study conducted at São Lucas Hospital. Endocan-1 and PIGF levels were quantified in maternal plasma using MagPlexTH-C microspheres system and analysed by ANCOVA adjusted by BMI, gestational age and maternal age. To estimate the difference between groups, mean ratio (MR) and 95\% confidence interval $(\mathrm{Cl})$ were calculated. Pearson correlation test was used to establish any association between Endocan-1 and PIGF levels. The null hypothesis was rejected when $p<0.05$.

Results: The group of patients was composed by normotensive $(n=67)$ and patients with PE $(n=50)$. A negative correlation between Endocan-1 and PIGF was noted in the entire group $(r=-0,605 ; p<0.001)$; as well as in the PE group $(r=-0,545 ; p<0.001)$.

Conclusion: Endocan-1 levels are increased in patients with PE and inversely correlated with PIGF levels. We suggest that it is important to analyze angiogenic and pro-inflammatory molecules concomitantly in women with PE to better understand the disease pathophysiology. Both molecules are strong competitors as a PE biomarkers and future work will examine any mechanisms connecting these factors in PE.

\section{Resumo}

Objetivo: Analisar o Endocan-1, um biomarcador de patologias vasculares endoteliais, e o Fator de crescimento placentário (PIGF), um fator angiogênico, marcador de disfunção placentária em pacientes com pré-eclâmpsia (PE). Métodos: Estudo caso-controle realizado no Hospital São Lucas. Os níveis de Endocan-1 e PIGF foram quantificados no plasma materno usando o sistema de microesferas MagPlexTH-C e analisados por ANCOVA ajustados por IMC, idade gestacional e idade materna. Para calcular a diferença entre os grupos, calculou-se a razão das médias (MR) e o intervalo de confiança de 95\% (Cl). O teste de correlação de Pearson foi utilizado para estabelecer a associação entre os níveis de Endocan-1 e PIGF. A hipótese nula foi rejeitada quando $p<0,05$.

Resultados: $O$ grupo de pacientes foi composto por normotensas $(n=67)$ e pacientes com PE $(n=50)$. Uma correlação negativa entre Endocan-1 e PIGF foi observada em todo o grupo de pacientes ( $r=-0,605 ; p<0,001)$; bem como no grupo PE $(r=-0,545 ; p<0,001)$.

Conclusão: Os níveis de endocan-1 estão aumentados em pacientes com PE e inversamente correlacionados com os níveis de PIGF. Sugerimos a importância de analisar moléculas angiogênicas e pró-inflamatórias concomitantemente em mulheres com PE para melhor compreender a fisiopatologia da doença. Ambas as moléculas são concorrentes fortes como biomarcadores de PE e o trabalhos futuros poderão avaliar quaisquer mecanismos que liguem esses fatores no PE. 


\section{Introduction}

Preeclampsia (PE) is one of the three major causes of maternal morbidity and mortality in the world, affecting $2 \%$ to $8 \%$ of all pregnancies. ${ }^{1}$ The etiology of PE remains unknown, but is thought to begin in placentation, when there is impairment in the vascular remodeling of the uterine spiral arteries leading to a decrease in perfusion and high uteroplacental resistance, creating an environment of hypoxia to placental and fetal tissues. Placental hypoxia results in the release of cytokines that when exposed to maternal circulation change the vascular response leading to widespread dysfunction of the maternal endothelium. ${ }^{2-7}$

Identifying a patient with $\mathrm{PE}$ is one of the major goals of prenatal care in order to refer the patient to high-risk pregnancy protocols, with specific treatment, and if necessary, plan the termination of pregnancy ${ }^{8}$.

The Endocan-1 molecule is a soluble proteoglycan expressed specifically in endothelial cells. This molecule has been studied in experimental models as well as in vivo and has been proved as a possible marker and predictor of many diseases ${ }^{9-11}$ associated with the vascular endothelium. ${ }^{9,12-21}$ Therefore, Endocan-1 appears to play a key role in tumor progression as well as in the regulation of the inflammatory process. $^{22}$

Regarding the association of Endocan-1 with PE, our group recently published a study that demonstrated a significant increase of Endocan-1 levels in maternal plasma, in women with preeclampsia, ${ }^{23}$ subsequently Chang et al., demonstrated the same association in placental tissue..$^{24}$ and Cakmak et al., associated higher serum endocan concentrations with the severity of the disease. ${ }^{25}$

A molecule that has been widely associated with the pathophysiology of diseases is placental growth factor (PIGF). It is produced by the placenta and has angiogenic action. During pregnancy PIGF is considered a marker of placental dysfunction. Plasma concentrations of PIGF are down-regulated in patients with PE and intrauterine growth restriction (IUGR), and it has been studied as a biomarker and risk predictor of developing PE. 6, 26, 27

To predict the chances of developing preeclampsia, it is important to associate molecules that are related to both cell growth and inflammatory cytokines, two key points of PE patients. We hypothesized that would be a negative correlation between Endocan-1 and PIGF. Thus objective of this study was to correlate the values of Endocan-1 and PIGF in the plasma of pregnant women with and without PE.

\section{Methods}

Observational, case-control study that included pregnant women with single fetus and with or without diagnosis of PE, who were hospitalized in São Lucas Hospital, Pontifical Catholic University of Rio Grande do Sul (HSL/PUCRS), Porto Alegre, Brazil, between 2010 and 2013. All samples were collected after obtaining informed, written consent. The study was approved by the institution Scientific and Ethics Research Committee (No. 11/05352-CEP). Preeclampsia for research was defined according to the National High Blood Pressure Education Program ${ }^{28}$ and to the VI Brazilian Guidelines on Hypertension $2010 .{ }^{29}$ blood pressure $\geqslant 140 / 90 \mathrm{mmHg}$, associated with pathological proteinuria $\geqslant 300 \mathrm{mg} / 24 \mathrm{~h}$ or proteinuria/creatininuria ratio $\geqslant 0.3$, after 20 weeks of gestation. The early onset PE was considered when PE developed with GA < 34 weeks. The PE group was called "PE pure" when pregnant women with superimposed PE and HELLP syndrome (Hemolysis, Elevated Liver Enzymes, Low platelet Count) were excluded from analysis. 
Data from maternal identification, physical examination (at hospital admission), previous medical history, maternal family history, laboratory tests, delivery, and the newborn were recorded. For both groups women were excluded if they had a previous diagnosis of kidney disease, liver disease, active infection, multiple gestation and/or lack of information in the database.

\section{Sample collection}

Maternal blood collection was performed after diagnosis (PE group) and hospitalization for delivery (normotensives - NT), in the third trimester of pregnancy. A total of 117 patients were collected (50 with PE and 67 - NT). Before delivery, $4 \mathrm{ml}$ of maternal blood was collected in ethylenediamine tetraacetic acid (EDTA) tubes. The samples were processed in the Nephrology Laboratory - HSL/PUCRS, and centrifuged at $2000 \mathrm{~g}$ for $10 \mathrm{~min}$, stored in a $600 \mu \mathrm{l}$ aliquots firstly, at $-20^{\circ} \mathrm{C}$ and then at $-80^{\circ} \mathrm{C}$ until the time of analysis. Laboratory exams to evaluate the severity of PE were conducted only in pregnant women with PE.

\section{Sample preparation}

Samples were prepared according to instructions of the Milliplex assay kit - MagPlexTH-C assay supplier. In order to calculate the concentration of molecules, MagPlexTH-System $\mathrm{C}$ - microspheres assay (MAGPIX® System, Luminex, Austin, Texas, USA) kit milliplex HADK2MAG-61K-05 and HCVD1MAG-67K02 (Millipore Corporation, Billerica, MA, USA) and Exponent software (Xponent 4.2) were used. The intraassay and inter-assay coefficient of variation was $<10 \%$. The linear correlation coefficient $(r)$ of Endocan-1 standard curve, according to the Luminex instrument, was $r=0.98$ and of PIGF $r=0.99$.

\section{Statistical analysis}

Statistical tests were conducted using the Statistical Package for Social Sciences version 19 (SPSS 19.0) for Windows, Graphpad Prism 6 and WINPEPI (PEPI-for-windows). Quantitative variables were presented as mean \pm standard deviation (SD) or median and interquartile range (IQR) as appropriate, Mann-Whitney U-test and Student $t$ test were used depending on the data distribution. For categorical variables, we used percentage and applied the Chi-square test or Fisher's exact test. Correlations between parameters were tested with Pearson's correlation coefficient. Data related to the dosage of Endocan-1 and PIGF were analyzed from the logarithmic transformation by Analysis of Covariance (ANCOVA) adjusted for BMI, gestational age (GA), and maternal age (presented as geometric mean). To estimate the proportional difference of cytokines between groups, the mean ratio (MR) and confidence interval of $95 \%$ were calculated. The magnitude of difference was estimated by Cohen effect size. The null hypothesis was rejected when $p<0.05$.

\section{Results}

\section{Study subjects}

Clinical and demographic characteristics, physical examination data, laboratory tests and data at the time of delivery are presented in table 1. Physical examination data are relative to the day of admission at HSL/PUCRS. 
For clinical data we opted to use de delivery GA data in order to use the same period of time in both groups. At the diagnosis of PE, 21 were preterm (10 with $\mathrm{GA}<34$ weeks) and 20 patients were diagnosed with severe $\mathrm{PE}$ due to systolic blood pressure $\geq 160 \mathrm{mmHg}$ and/or diastolic blood pressure $\geq 110 \mathrm{mmHg}$.

Table 1. Socio-demographic data and maternal and perinatal outcomes from NT and PE groups

\begin{tabular}{|c|c|c|c|}
\hline Parameters & NT (67) & PE (50) & p-value \\
\hline Maternal age, years & $26 \pm 5$ & $26 \pm 6.8$ & 0.10 \\
\hline White, n (\%) & $34(52)$ & $31(65)$ & 0.25 \\
\hline Primiparous, n (\%) & $28(42)$ & $25(51)$ & 0.35 \\
\hline Chronic hypertension, n (\%) & $0(0)$ & $12(24.5)$ & - \\
\hline Previous PE, n (\%) & $1(1.5)$ & $12(24.0)$ & - \\
\hline $\begin{array}{l}\text { BMI, } \mathrm{kg} / \mathrm{m}^{2} \text { (weight at end of } \\
\text { pregnancy) }\end{array}$ & $30.4 \pm 5.8$ & $32.3 \pm 5.4$ & 0.081 \\
\hline $\mathrm{SBP}, \mathrm{mmHg}$ & $119 \pm 10$ & $157 \pm 17$ & $<0.001^{*}$ \\
\hline $\mathrm{DBP}, \mathrm{mmHg}$ & $75 \pm 8$ & $101 \pm 14$ & $<0.001^{*}$ \\
\hline GA at delivery, weeks & $39.6 \pm 1.4$ & $36.7 \pm 3.7$ & $<0.001^{*}$ \\
\hline Cesarean section, n (\%) & $22(32.8)$ & $38(76.0)$ & $<0.001^{*}$ \\
\hline 5-minute Apgar, $\mathrm{n}^{* *}$ & $9.4 \pm 0.6$ & $8.72 \pm 1.21$ & $<0.001^{*}$ \\
\hline Birth weight, $\mathrm{Kg}$ & $3,393 \pm 458$ & $2,789 \pm 904$ & $<0.001^{*}$ \\
\hline Placental weight, $\mathrm{Kg}$ & $649 \pm 142$ & $590 \pm 179$ & 0.063 \\
\hline Hematocrit, \% & $35.2 \pm 2.5$ & $36.22 \pm 3.51$ & 0.14 \\
\hline Hemoglobin, g/dL & $11.6 \pm 0.9$ & $12.31 \pm 1.28$ & $0.004^{*}$ \\
\hline Platelets, mm³ (mil) & & $211.00 \pm 59.05$ & - \\
\hline Creatinine, mg/dL & & $0.81 \pm 0.21$ & - \\
\hline Proteinuria, $\mathrm{P} / \mathrm{C}$ rate & & $0.67[0.42 ; 2.2]$ & - \\
\hline Fasting glucose, $\mathrm{mg} / \mathrm{dL}$ & $75.2 \pm 9.3$ & $78.9 \pm 13.7$ & 0.26 \\
\hline
\end{tabular}

NT - Normotensive pregnancy; PE - Preeclampsia; GA - Gestational age; BMI - Body Mass Index; SBP -Systolic blood pressure; DBP - diastolic blood pressure (at admission); Data are presented as mean \pm SD (Student's t-test), or absolute numbers and percentage (Fisher's exact test), as appropriate. * $p<0.05$ between NP and PE. ** In control group, non-newborn received Apgar $<7$; and in PE group, 2 patients received Apgar $<7$. (Table is based on a previous published study ${ }^{23}$ ).

\section{Analysis of study molecules}

The mean levels of PIGF in NT and PE pure was $58.4 \mathrm{pg} / \mathrm{mL}$ versus $33.05 \mathrm{pg} / \mathrm{mL}$ and in Endocan-1 was $2032.6 \mathrm{pg} / \mathrm{mL}$ versus $3357.8 \mathrm{pg} / \mathrm{mL}$, respectively. For statistical analysis the logarithmic transformation was made and ANCOVA test was applied. Lower levels of PIGF were found in the PE pure group (MR=0.38; 95\% Cl: 0.15-0.95; $p=0.041)$, (Cohen's $D=0.54$ ) and higher levels of Endocan-1 were found in maternal plasma in PE pure group (MR=1.56; $95 \% \mathrm{Cl}: 1.22-2,01, \mathrm{p}=0.001)$ with a moderate effect size (Cohen's $\mathrm{D}=$ 0.93) - Recently published by our group ${ }^{23}$.

When PE group was divided into early PE (<34 weeks; $\geq 34$ weeks and controls), we found in early PE lower levels of PIGF $(p=0,009)$ and higher levels of Endocan-1 $(p<0,001)$.

Finally, a negative correlation between Endocan-1 and PIGF was noted in the entire group ( $r=-$ $0,605 ; p<0.001)$; as well as in the PE group $(r=-0,545 ; p<0.001)$ (Figure 1). 


\section{Discussion}

PIGF was approximately $60 \%$ lower in patients with PE pure as compared to the control group. In contrast, the level of Endocan-1 between the two groups was $56 \%$ higher in patients with PE pure, and it was seen a strong negative correlation between the two molecules. The early PE group also showed its importance in molecular analysis, when early PE presented a statistically lower level of PIGF and higher level of Endocan-1. It could suggest both molecules as biomarker of early onset PE.

Many factors that may be related to PE has been proposed, but the most prominent have been associated with protein receptors of the VEGF family, particularly sVEGFR1 (soluble vascular endothelial growth factor receptor-1), PIGF, and VEGF (vascular endothelial growth factor). ${ }^{30,31}$

The circulating PIGF in human beings is predominantly PIGF-1 (currently there are PIGF 1 to 4 ), mainly produced by the placenta, significantly reduced in $\mathrm{PE},{ }^{32,33}$ due to a negative regulation that occurs under hypoxia, ${ }^{34}$ even before the onset of PE symptoms. ${ }^{30}$ However, the role of PIGF in the pathogenesis of PE is not entirely known, partly because its physiologic action is not fully understood. In 2008, however, Osol, et al., demonstrated PIGF-1 as a potent vasodilator particularly on uterine arteries, mediated specially by the release of nitric oxide in pregnancy that could also regulates the venous tone. In the presence of higher levels of sVEGFR-1, PIGF is down regulated, which could diminish the vasodilation process and lead to hypertension, seen in patients with PE. ${ }^{35}$

Since early pregnancy cell injury occurs in the extracellular matrix and in the vessel walls of the maternal decidua to create a propitious environment for embryo implantation. Ischemic lesions in the placenta resulting from a poor remodeling of decidual vessels release molecular mediators in the maternal circulation, creating an imbalance between vasoconstrictors and vasodilators, culminating in PE syndrome with a progressing systemic response. However, it is thought that in normal pregnancy the syncytiotrophoblast self-renews leaving apoptotic debris in the maternal circulation, what leads to an expected inflammatory response during placental growth.

The significant increase in Endocan-1 concentration seen in maternal plasma might be due to this intense response to this process of physiological development, together with the increased release of proinflammatory cytokines already observed in previous studies. ${ }^{7}$

Is questioned which molecule(s) would be mediating the inverse correlation found between PIGF and Endocan-1 and which one seems to firstly change in the pathophysiology of the disease. There is a lack of studies to answer this question clearly. Its known that studies that evaluated both molecules in the first trimester of pregnancy, in separate, showed that both Endocan-1 and PIGF are decreased in patients who developed PE. ${ }^{36}$ Findings from our group demonstrated that PIGF remains down-regulated, but Endocan-1 is tends to increase throughout gestation. This occurs, in part, due to the ischemia that begins and compromises maternal circulation.

All of patients of our study were included in the third trimester of gestation and the level of cytokines was adjusted for gestational age, to minimize the influence of this confounding factor in the results.

PIGF is a placental growth factor and the placenta plays a crucial role in fetal nutrition. Endocan-1, a cytokine of predominantly inflammatory nature, injures the vasculature and therefore contributes to the reduction of placental flow, IUGR, and low placental weight. 
To our knowledge, there are no complete articles in the literature that correlate these two molecules in PE.

Therefore, the study contributed to previous findings by demonstrating decreased PIGF and increased Endocan-1 in the third trimester of pregnancy in PE and its importance in early onset disease. We believe that, in addition to PIGF, promising molecule in studies involving PE, Endocan-1 also seems to play a role in the PE pathogenesis and would be related with some clinical findings of the disease, but future researches should be done to clarify these hypotheses.

\section{Conclusion}

This study evaluated the presence of Endocan-1 and PIGF molecules in maternal plasma; it also correlated the levels of this cytokine in patients with PE and NT. In patients with PE, Endocan-1 was significantly increased and PIGF decreased in maternal plasma. The role of this cytokines in the preeclampsia pathophysiology needs to be continuously studied.

\section{References}

1. Duley L. The global impact of pre-eclampsia and eclampsia. Semin Perinatol. 2009; 33: 130-137.

2. Warrington JP, George EM, Palei AC, Spradley FT, Granger JP. Recent advances in the understanding of the pathophysiology of preeclampsia. Hypertension. 2013;62:666-73.

3. Lamarca $B$. The role of immune activation in contributing to vascular dysfunction and the pathophysiology of hypertension during preeclampsia. Minerva Ginecol. 2010; 62: 105-120.

4. Gilbert JS, Ryan MJ, LaMarca BB, Sedeek M, Murphy SR, Granger JP. Pathophysiology of hypertension during preeclampsia: linking placental ischemia with endothelial dysfunction. Am J Physiol Heart Circ Physiol. 2008;294: H541-550.

5. Laresgoiti-Servitje E. A leading role for the immune system in the pathophysiology of preeclampsia. $J$ Leukoc Biol. 2013; 94:247-257.

6. Duhig KE, Chappell LC, Shennan AH. How placental growth factor detection might improve diagnosis and management of pre-eclampsia. Expert Rev MolDiagn. 2014; 14: 403-406

7. Pinheiro MB, Martins-Filho OA, Mota AP, Alpoim PN, Godoi LC, Silveira AC, et al. Severe preeclampsia goes along with a cytokine network disturbance towards a systemic inflammatory state. Cytokine. 2013; 62:165-73.

8. Bewley S, Shennan A. HYPITAT and the fallacy of pregnancy interruption. Lancet. 2010; 375:119

9. Lassalle P, Molet S, Janin A, Heyden JV, Tavernier J, Fiers W, et al. ESM-1 is a novel human endothelial cell-specific molecule expressed in lung and regulated by cytokines. J Biol Chem. 1996;271: 20458-64.

10. Depontieu F, de Freitas Caires N, Gourcerol D, Giordano J, Grigoriu B, Delehedde M, et al. Development of monoclonal antibodies and ELISA specific for the mouse vascular endocan. J Immunol Methods. 2012; 378: 88-94.

11. Scherpereel A, Gentina T, Grigoriu B, Senechal S, Janin A, Tsicopoulos A, et al. Overexpression of endocan induces tumor formation. Cancer Res. 2003;63: 6084-6089. 
12. Bechard D, Meignin V, Scherpereel A, Oudin S, Kervoaze G, Bertheau P, et al. Characterization of the secreted form of endothelial-cell-specific molecule 1 by specific monoclonal antibodies. J Vasc Res. 2000; 37: 417-25.

13. Grigoriu BD, Depontieu F, Scherpereel A, Gourcerol D, Devos P, Ouatas T, et al. Endocan expression and relationship with survival in human non-small cell lung cancer. Clin Cancer Res. 2006; 12: 4575-4582.

14. Ziol M, Sutton A, Calderaro J, Barget N, Aout M, Leroy V, et al. ESM-1 expression in stromal cells is predictive of recurrence after radiofrequency ablation in early hepatocellular carcinoma. $J$ Hepatol. 2013; 59: 1264-70.

15. Nault JC, Guyot E, Laguillier C, Chevret S, Ganne-Carrie N, N'Kontchou G, et al. Serum proteoglycans as prognostic biomarkers of hepatocellular carcinoma in patients with alcoholic cirrhosis. Cancer Epidemiol Biomarkers Prev. 2013; 22: 1343-1352.

16. Kim JH, Park MY, Kim CN, Kim KH, Kang HB, Kim KD, et al. Expression of endothelial cell-specific molecule-1 regulated by hypoxia inducible factor-1alpha in human colon carcinoma: impact of ESM-1 on prognosis and its correlation with clinicopathological features. Oncol Rep. 2012; 28: 1701-1708.

17. Kang YH, Ji NY, Han SR, Lee Cl, Kim JW, Yeom YI, et al. ESM-1 regulates cell growth and metastatic process through activation of NF-kappaB in colorectal cancer. Cell Signal. 2012; 24: 1940-1949.

18. De Freitas Caires N, Legendre B, Parmentier E, Scherpereel A, Tsicopoulos A, Mathieu D, et al. Identification of a $14 \mathrm{kDa}$ endocan fragment generated by cathepsin $\mathrm{G}$, a novel circulating biomarker in patients with sepsis. Journal of pharmaceutical and biomedical analysis. 2013;78-79: 45-51.

19. Paulus P, Jennewein C, Zacharowski K. Biomarkers of endothelial dysfunction: can they help us deciphering systemic inflammation and sepsis? Biomarkers.2011; 16Suppl 1: S11-21.

20. Tadzic R, Mihalj M, Vcev A, Ennen J, Tadzic A, Drenjancevic I. The effects of arterial blood pressure reduction on endocan and soluble endothelial cell adhesion molecules (CAMs) and CAMs ligands expression in hypertensive patients on Ca-channel blocker therapy. Kidney Blood Press Res. 2013; 37: 103-115.

21. Janke J, Engeli S, Gorzelniak K, Feldpausch M, Heintze U, Bohnke J, et al. Adipose tissue and circulating endothelial cell specific molecule-1 in human obesity. HormMetab Res. 2006; 38: 28-33.

22. Scherpereel A, Depontieu F, Grigoriu B, Cavestri B, Tsicopoulos A, Gentina T, et al. Endocan, a new endothelial marker in human sepsis. Crit Care Med. 2006; 34: 532-537.

23. Hentschke MR, Lucas LS, Mistry HD, Pinheiro da Costa BE, Poli-de-Figueiredo CE. Endocan-1 concentrations in maternal and fetal plasma and placentae in pre-eclampsia in the third trimester of pregnancy. Cytokine. 2015; 74: 152-156.

24. Chang X, Bian Y, Wu Y, Huang Y, Wang K, Duan T. Endocanof the maternal placenta tissue is increased in pre-eclampsia. Int J ClinExpPathol. 2015;11: 14733-40. eCollection 2015.

25. Cakmak M, Yilmaz H, Bağlar E, Darcin T, Inan O, et al. Serum levels of endocan correlate with the presence and severity of pre-eclampsia. Clin Exp Hypertens. 2016;38:137-42.

26. Augustin AJ. Placenta Growth Factor (PIGF) and Retinal Vascular Diseases--Current Knowledge from Experimental and Clinical Studies. KlinMonbl Augenheilkd. 2016;233: 57-65. 
27. Chappell LC, Duckworth S, Seed PT, Griffin M, Myers J, Mackillop L, et al. Diagnostic accuracy of placental growth factor in women with suspected preeclampsia: a prospective multicenter study. Circulation. 2013; 128: 2121-2131.

28. Report of the National High Blood Pressure Education Program Working Group on High Blood Pressure in Pregnancy. Am J Obstet Gynecol. 2000; 183: S1-S22.

29. VI Brazilian Guidelines on Hypertension. Arq Bras Cardiol. 2010; 95(1 Suppl): 1-51.

30. Levine RJ, Maynard SE, Qian C, Lim KH, England LJ, Yu KF, Schisterman EF, Thadhani R, Sachs BP, Epstein FH, Sibai BM, Sukhatme VP, Karumanchi. SA. Circulating angiogenic factors and the risk of preeclampsia. N Engl J Med. 2004; 350: 672-683.

31. Bates DO. An unexpected tail of VEGF and PIGF in pre-eclampsia. Biochem Soc Trans. 2011; 39: 15761582.

32. Reuvekamp A, Velsing-Aarts FV, Poulina IE, Capello JJ, Duits AJ. Selective deficit of angiogenic growth factors characterises pregnancies complicated by pre-eclampsia. Br J ObstetGynaecol. 1999;106: 10191022.

33. Thadhani R, Mutter WP, Wolf M, Levine RJ, Taylor RN, et al. First trimester placental growth factor and soluble fms-like tyrosine kinase 1 and risk for preeclampsia. J ClinEndocrinolMetab. 2004; 89: 770-775.

34. Munaut C, Lorquet S, Pequeux C, Blacher S, Berndt S, et al. Hypoxia is responsible for soluble vascular endothelial growth factor receptor-1 (VEGFR-1) but not for soluble endoglin induction in villous trophoblast. Hum Reprod. 2008; 23: 1407-1415.

35. Osol G, Celia G, Gokina N, Barron C, Chien E, et al. Placental growth factor is a potent vasodilator of rat and human resistance arteries. Am J Physiol Heart \& Circ. 2008; 294: H1381-387.

36. Schuitemaker JHN, Cremers TIFH, Van Pampus MG, Scherjon SA, Faas MM. Changes in endothelial cell specific molecule 1 plasma levels during preeclamptic pregnancies compared to healthy pregnancies. Pregnancy Hypertens. 2018;12:58-64.

Figure 1. Correlation between Endocan-1 and PlGF
A) Correlation between Endocan-1 and PlGF in the entire group
B) Correlation between Endocan-1 and PIGF PE group 
a) Correlation between Endocan-1 and PIGF in the entire group

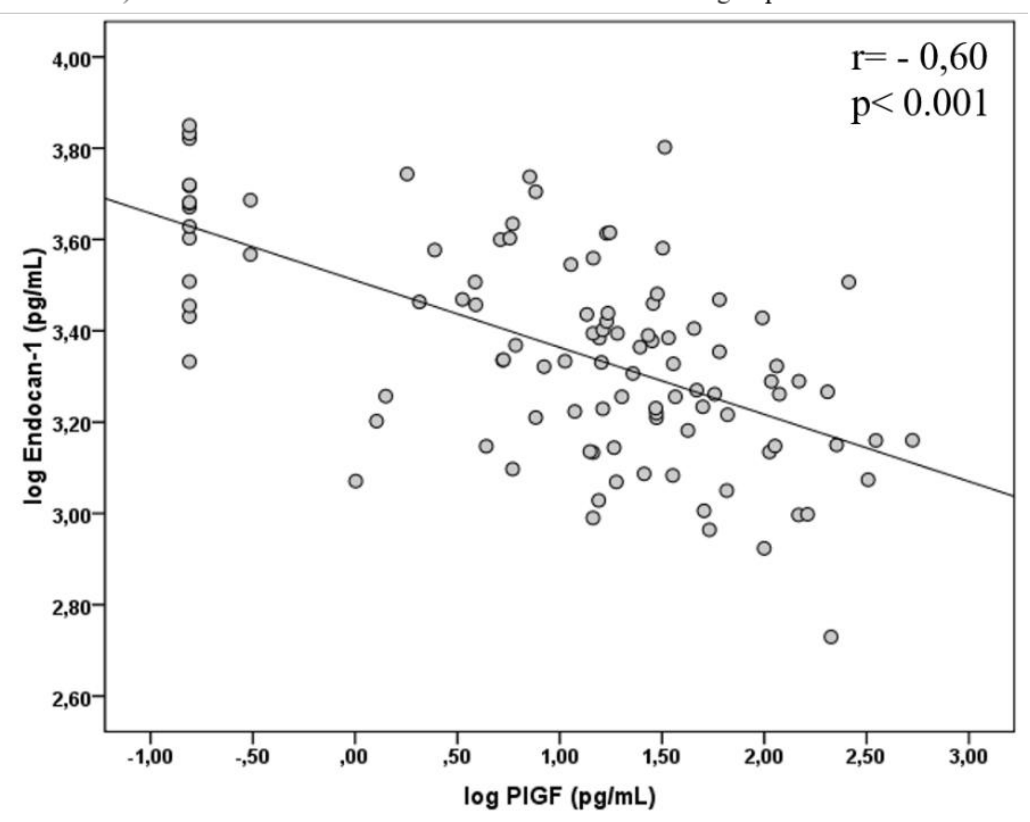

b) Correlation between Endocan-1 and PIGF PE group

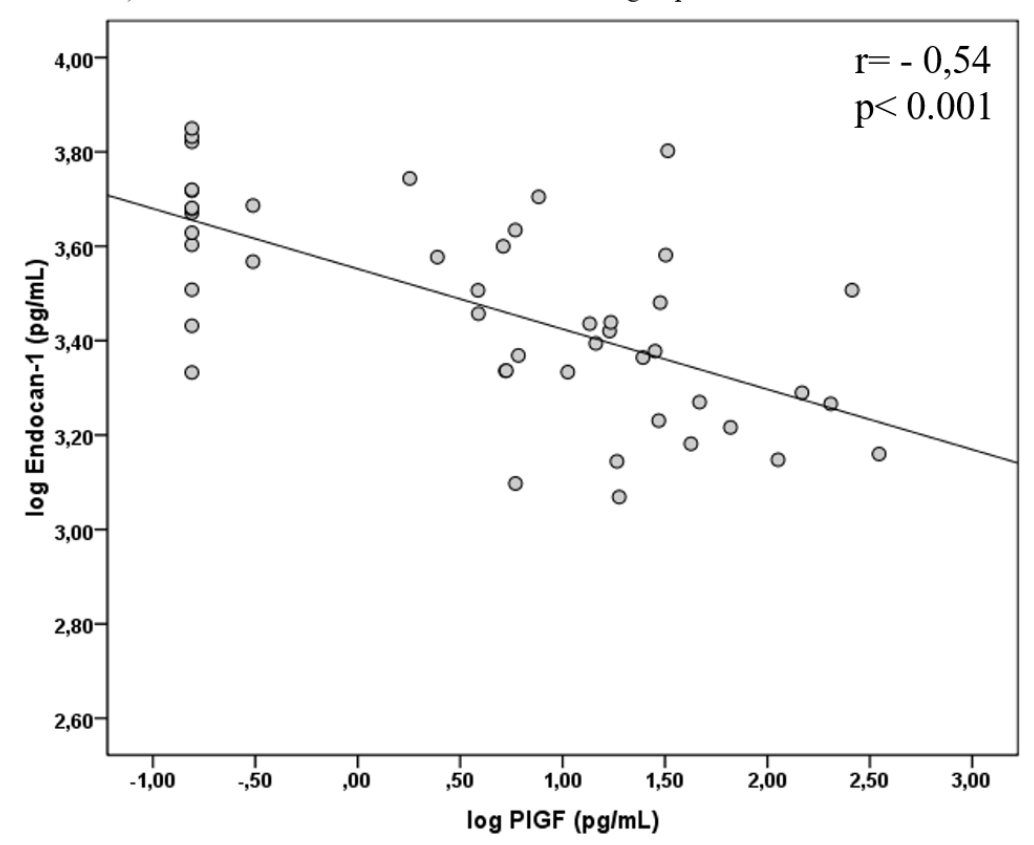

